\title{
ASIAN CULTURAL OBJECTS IN EUROPE. ART MARKET EXPANSION AND THE ILLICIT TRAFFICKING OF CULTURAL HERITAGE: AN OUTLINE OF LEGAL ISSUES
}

\section{Introduction}

Ever since art has been made, there has been a market for it. ${ }^{1}$

\begin{abstract}
Although the first entries on the history of the art market begin with Egyptian art dealers shipping goods to Crete, ${ }^{2}$ the $21^{\text {st }}$ century hub of the art world moves further east. Mainland China and Hong Kong have become vibrant art market centres. ${ }^{3}$ In the face of the growing visibility of those markets and erratic geopolitical times, the issue of Asian art objects found nowadays in Europe is a wide-ranging and prominent concern. The aim of this study is to bring attention to the co-relation between the development of the Asian art market along with its visibility in the West and the illicit trafficking of Asian cultural goods paradoxically fostering the improvement of preventive measures. Since the Asian art market is not homogenous, the following study focuses primarily on the context of transactions between Mainland China, Hong Kong, and the Member States of the European Union. ${ }^{4}$ As the most recurring objects in the context of illicit export and trade of Asian cultural goods are antiques, this study brings forward cases of such practices. Before exploring the case of Eastern heritage in the West, an overview of the actors on the Asian art market needs to be brought forward, since the institutional importance of cultural entities influences the status of cultural objects, both in the country of origin and abroad.
\end{abstract}

\footnotetext{
1 D. Boll, Art for Sale, Ostfildern 2011, p. 14.

2 Ibidem.

3 The Art Market in 2015, Artprice.com AMMA, https://imgpublic.artprice.com/pdf/rama2016_en.pdf (accessed: 10.08.2016).

4 The scope of cooperation between the Member States as far as the return of cultural objects removed from the territory of a member state is specified in Directive 2014/60/EU of the European Parliament and of the Council of 15 May 2014 on the Return of Cultural Objects Unlawfully Removed from the Territory of a Member State and amending Regulation (EU) No. 1024/2012.
} 


\section{East meets West - the visibility of the Asian art market in the West}

Despite the indirectness of origins of the cultural exchange between China and the West, the first documented examples of lasting relationships date back to the $13^{\text {th }}$ century, when first trade routes linking China to Europe were established. ${ }^{5}$ Marco Polo, who traveled to China as a trader, accounts decorative art and architecture - while the Western art was introduced to the Chinese court in the $14^{\text {th }}$ century. In the following centuries, the transfer of goods intensified following the establishment of maritime trade links between Portugal and Macau. ${ }^{6}$ The expansion of the Dutch East India Company fostered the trade of Chinese ceramics in Europe (which still constitute a principal commodity on the current market) and influenced Western art and philosophy.

Asian art market in particular has gained a worldwide renown thanks to the world's increasing fascination and interest in Asian art and culture. ${ }^{8}$ The increase is even more visible thanks to the extension of Western auction houses, such as Sotheby's or Christie's, in Asia. After a decrease in 2015, 2016 was a remarkable success on the Chinese art market. ${ }^{9}$ The approach of auction houses is as visible as in the case of major Western art galleries opening branches to the East. ${ }^{10}$

What draws special attention is the clear division of the markets of Mainland China and Hong Kong, as far as the results are concerned, and as opposed to the geopolitical point of view. Hong Kong, a British territory from the First Opium War $(1839-1842)^{11}$ till 1997, is a special administrative region of the People's Republic of China and is granted much autonomy, however, plays a key role in establishing the status of the whole Chinese market. Moreover, the TEFAF 2017 report states that Asia has proved to be the biggest area worldwide as far as art and antiques auction sales are concerned. ${ }^{12}$ According to McAndrew, China is the second market for

5 P. Gladston, Contemporary Chinese Art: A Critical History, London 2014.

${ }_{6}$ Followed by the establishment of one of the main freeports - discussed in the paper.

7 P. Gladston, Contemporary Chinese Art...

8 S.H. Hsieh, J.P. Lee, L.Y. Tzeng, Art as an Investment: Empirical Study of Asian Contemporary and Chinese 20 th Century Modern Art, http://www.fin.ntu.edu.tw/ conference/conference2010/ proceedings/proceeding/11/11-1(A40).pdf (accessed: 12.08.2016).

9 Defying all forecasts: China upped 18\%, dominated the global Art Market in the first half of 2016, Artprice.com, https://www.artprice.com/artmarketinsight/artpricecom-defying-all-forecasts-chinaupped-18-dominated-the-global-art-market-in-the-first-half-of-2016 (accessed: 21.10.2016).

10 More: B. Boucher, The Art Market Moves East: How Gagosian, David Zwirner, and 14 Other Western Art Businesses Are Trying to Expand to Asia, Artnet, 15 November 2017, https://news.artnet. $\mathrm{com} / \mathrm{market} /$ asia-round-up-galleries-auction-houses-1135454 (accessed: 17.11. 2017).

11 S. Tsang, A Modern History of Hong Kong, London 2007.

12 R.A.J. Pownall, TEFAF Art Market Report 2017. 
art and antiques (after the United States) ${ }^{13}$ however, as the context of this paper is concerned, it is worth mentioning that in China, as a communist country, art trade was not considered legal until the late $1980 \mathrm{~s} .{ }^{14}$ Other recent studies ${ }^{15}$ bring attention to the downfall of the popularity of Chinese antiques abroad and an increase of the demand in China. (See: Fig. 1)

\section{1-2016 Global Total Sales Value (USD) of Chinese Art and Antiques}

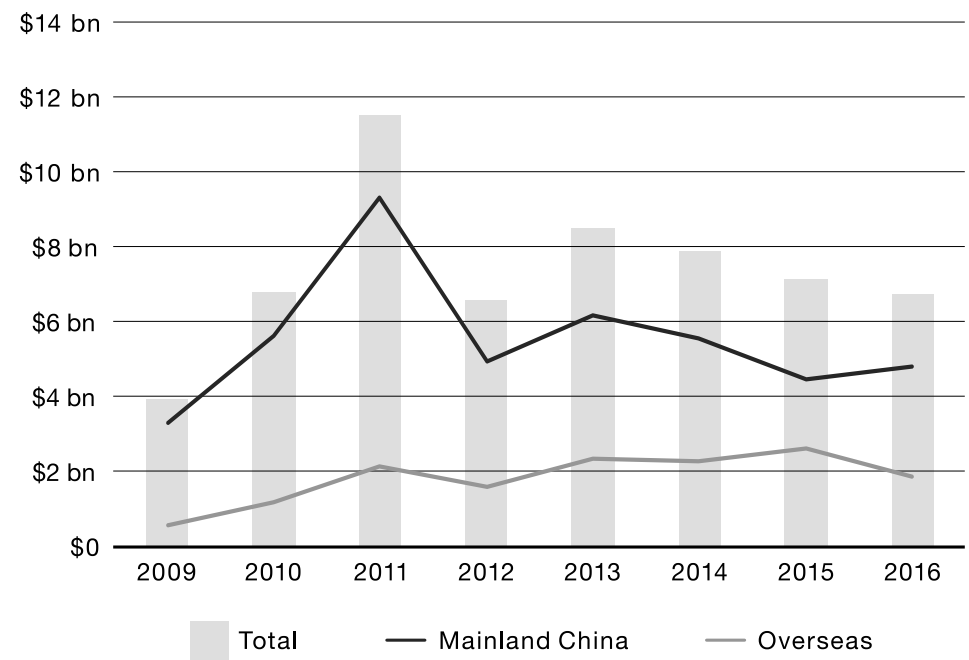

Figure 1. The increasing discord of the sales of Chinese art and antiques between Mainland China and overseas (North America and Europe)

Source: www.cn.artnet.com/en/chinese-art-auction-market-report/\#download (accessed: 11.11.2017)

Despite the overall downfall tendency of Asian antiques sales outside of Mainland China (on the other hand, paradoxically, it is worth to mention the ongoing successful sales of Chinese antiques abroad, e.g. the US \$ 3.3 million Ya Yi Fangding bronze from the Shang dynasty sold during the Asian Art Week in September 2017 at Christie's New York), the issue of illicit trafficking is not affected by the supposedly lowering demand.

13 C. McAndrew, TEFAF Art Market Report 2014: The Global Art Market, with a Focus on the US and China, Maastricht 2014, qtd. in: O. Velthius, S.B. Curioni, Cosmopolitan Canvases: The Globalization of Markets for Contemporary Art, Oxford-New York 2015, p. 2.

14 O. Velthius, S.B. Curioni, Cosmopolitan Canvases..., p. 1.

15 E.g. The Global Chinese Art Auction Market Report 2016 presented by Artnet and the China Association of Auctioneers (CAA). 


\title{
Legal Issues - illicit trafficking of Asian cultural objects in Europe
}

\author{
Art is one of the most unregulated industries on the planet. ${ }^{16}$
}

The key legal issues related to the Asian art market refer to provenance lacunae. In the context of antiquities, the most common risk is the fact that the works have either dubious authenticity or might have been looted. Another issue in question is the provenance research related to the droit de suite. the Artist's Resale Right, existing in some countries, entitling the author of original works of art to a royalty every time a work is sold via an art dealer or an auction house. ${ }^{17}$ The case is closely linked to the provenance research as the right applies to the heirs in the period up to 70 years after the artist's death. The idea of implementing the right in China has brought major concerns that the complex provenance proving process will slow down the flow on the art market, however, the decision to implement it could clear the confusion arising from dubious certificates of authenticity and could therefore influence reliability of the art market professionals and, subsequently, the trust of buyers. In addition, in March 2016, the Chinese government imposed new art market regulations that are expected to result in a standardisation of other areas of the domestic art market. ${ }^{18}$ The case of authenticity and provenance research of Asian cultural objects present in Europe includes a variety of factors. The first and foremost aspect to be explored is the division of objects, as the category determines solutions to be implemented. Cultural heritage sites had been raided by troops and smugglers even before the proper art market was born. The pieces in question usually fall within one of the following categories: 1) looted, 2) unrightfully bought, 3) illegally excavated, 4) fake.

Looted art objects are usually an outcome of armed conflicts and since they are, in general, exported from the country being looted, the majority of restitution claims involve an international law component. ${ }^{19}$ However, it was not before the end of the $19^{\text {th }}$ century that the first legal regulations preventing such acts were implemented. The Hague Regulations following the peace conferences of 1899 and

16 J. Zarobell, How Freeports Operate on the Margins of the Global Art Market, 14.07.2017, https:// www.artsy.net/article/artsy-editorial-freeports-operate-margins-global-art-market (accessed: 11.11.2017).

17 Artist's Resale Right, Intellectual Property Office, https://www.gov.uk/guidance/artistsresale-right (accessed: 7.05.2017).

18 Art and Finance Report 2016, Deloitte, ArtTactic, https://www2.deloitte.com/content/dam/ Deloitte/lu/Documents/financial-services/artandfinance/lu-en-artandfinancereport-21042016. pdf (accessed: 11.11.2017).

19 M.A. Renold, Cross-border restitution claims of art looted in armed conflicts and wars and alternatives to court litigations, Directorate General for Internal Policies Policy Department C: Citizens' Rights and Constitutional Affairs, 2016. 
1907 (Convention II on the Laws and Customs of War on Land and Convention IV respecting the Laws and Customs of War on Land and its annexed regulations) were, nevertheless, ignored during the conflicts that followed, not to mention the conflicts that preceded.

The (late) Pierre Bergé's case is an example of the fatal consequences of transfrontier art loot. The two $18^{\text {th }}$-century bronze fountainheads (a rabbit and a rat) offered at auction by Christie's in 2009, were proved to had been stolen from the Old Summer Palace by the British and French forces during the Second Opium War of $1860 .{ }^{20}$ The pieces, part of Pierre Bergé's collection, were returned to China by François-Henri Pinault, chief executive officer of Kering, the company that owns Christie's, in 2013. The adopted solution, unconditional restitution, donation, and financial compensation ${ }^{21}$, pursuant to the 1995 UNIDROIT Convention on Stolen or Illegally Exported Cultural Objects, Chapter II - Restitution of Stolen Cultural Objects, Article 3(1), was meant to secure the trade and diplomatic relations between France and China. Therefore, restitution law, as such, is not only a means of providing legal solutions to a given issue, but constitutes a guidebook on moral, political, and emotional problem-solving practices in the art world.

"Restitution also took on special meaning on the basis of other branches of law, above all, of international law. In this, it means the return of state and private property looted during armed conflict. However, it must be pointed out that as a consequence of the evolution and persistent broadening of the scope of the norms of international law, restitution began, in addition, to comprise the return of property illegally lost for other reasons, but this, too, related to international relations." 22

Restitution practices apply not only to wartime plunder but also theft. ${ }^{23} \mathrm{Un}$ rightfully bought objects stay in the market as a result of a variety of factors. Their acquisition is usually accompanied by the lack of due diligence ${ }^{24}$ on the buyer's part, it may therefore be a bona fide purchase. The asymmetry of information as well as the "culture of ignorance" 25 facilitates the illegal trafficking of goods on the art market. Some cases of cultural treasures bargain can also be tagged as "post

20 A. Wallace, A.L. Bandle, M.A. Renold, Case Two Bronze Animal Heads-China and Pierre Bergé, https://plone.unige.ch/art-adr/cases-affaires/two-bronze-animal-heads-2013-china-and-pierreberge (accessed: 11.11.2017).

21 Ibidem.

22 K. Zeidler, Restitution of Cultural Property. Hard Case - Theory of Argumentation - Philosophy of Law, Gdańsk-Warsaw 2016, p. 27.

23 W. Kowalski, Types of Claims for Recovery of Lost Cultural Property, "Museum International" 2005, Vol. LVII, No. 4 (228), p. 97.

${ }^{24}$ For "due diligence measures" see: K. Zalasińska, Dobra wiara jako przestanka ochrony nabywców keradzionych dziet sztuki. Wybrane zagadnienia, "Palestra" 2010, No. 5/6, p. 53.

25 W. Szafrański, Nowe zjawiska w obrebie przestępczości na rynku sztuki w Polsce [in:] Przestępczosíc przeciwko dziedzictwu kulturowemu. Diagnoza, zapobieganie, zwalczanie, eds. M. Trzciński, O. Jakubowski, Wrocław 2016, p. 46. 
1970 restitution claims" since it was in 1970 that the Convention on the Means of Prohibiting and Preventing the Illicit Import, Export and Transfer of Ownership of Cultural Property was implemented. According to the principles of the Convention, each excavated element needs and assigned Object-ID to facilitate its identification and tracking. ${ }^{26}$ The convention specifies the need for an export certificate (Art. 6), and the Law of the People's Republic of China on Protection of Cultural Relics (No. 11 of the Standing Committee of the National People's Congress, effective as of 19 November 1982, amended in 1991, 2002, 2007, 2013, 2015) also "renders it illegal to export such items without an export license". ${ }^{27}$ The case of 3000 Chinese Archeological Objects transferred to the United Kingdom through illegal export was also, most probably, a result of illicit excavation. ${ }^{28}$ In 1994, the pieces were accidentally discovered by the Scotland Yard which lead to an international cultural heritage trafficking gang and resulted in a 1995 raid and seizure of 6,000 illegally exported goods from China and other areas. After the identification of the dealers, the negotiations over returning the objects in questions resulted in an out-of-court settlement. In addition, as far as the provenance research is concerned, since the objects were excavated, therefore, not documented before, the researchers needed to track provenance of each and every object. It is worth mentioning, that the Chinese registry of cultural goods is not yet fully revised which might also influence the difficulties in establishing authenticity and origin of cultural treasures on the market.

While fake masterpieces of European masters are common on the market, Asian antiquities are no less affected by the same practice. While not explicitly fakes, Chinese objects of everyday use including cups, vases, and furniture are often identified as ancient valuables even if made in the $20^{\text {th }}$ century, expressly for export. The European fascination with Asian culture at the turn of the twentieth century stimulated the production of artefacts imitating ancient objects. For instance, whilst cups bought from a Chinese dealer at the beginning of the $20^{\text {th }}$ century might look like nephrite jade, they are, most probably, a similar hardstone without the same qualities. With the passage of time, the heirs of such collectors, develop an emotional approach to their valuables and may not accept such opinion and low valuation of their belongings.

A vast majority of cultural objects present on the art market is of dubious provenance and this accounts to the fact that their import is related to specific

26 Operational Guidelines for the Implementation of the Convention on the Means of Prohibiting and Preventing the Illicit Import, Export and Transfer of Ownership of Cultural Property, UNESCO, Paris, 1970.

${ }_{27}$ M. Yu, E. Velioglu Yildizci, M.A. Renold, 3000 Archeological Objects - Cbina and Two British Dealers, https://plone.unige.ch/art-adr/cases-affaires/3000-archeological-objects-2013-china-andtwo-british-dealers (accessed: 11.11.2017).

28 Ibidem. 
tax regulations. As far as the Asian context is concerned, the main issue related to this aspect is the institution of freeports. Tax rates on art import vary from one country to another e.g. while in Brazil customs duties on art are an unsurmountable factor causing European art galleries to avoid shipping goods purchased by Brazilian buyers, and, therefore, limit the trade, freeports granting exemption of taxes and providing discrete, well-protected storages, located also in Asia, foster transactions. Such conditions favour abuse. Mainland China, Singapore, and Hong Kong reign supreme as the key tax-free warehouse providers in Asia. Freeports, or SEZs (Special Economic Zones) ${ }^{29}$ fall under the, so-called, "secrecy jurisdiction"30 and, therefore, cannot be regulated or taxed by any government, ${ }^{31}$ which results in anomalies on the market.

Nonetheless, the listed factors supporting the development of measures avoiding legal, financial, and moral consequences resulting from illicit trafficking of cultural goods, might be perceived as a double-edged sword. With the development of online stores and databases, on the one hand, art trade has never been so effortless, but on the other, it has never been so public, and, therefore, facile to track and prove. The improvement of technology proves to facilitate the focalisation of currently available measures to support the combat against art loot and illicit trafficking. With the innovative approach of cultural heritage experts, looted pieces tracking has become a matter of satellite mapping ${ }^{32}$ dependent on analysing satellite sensor signals in various electromagnetic frequencies. ${ }^{33}$ In addition, with half a million of items categorised as "Chinese antiques" available on one of the most recognised online stores, the tracking of unverified sellers is possible thanks to the contact information provided, however, in most cases, the disclosure of an illicit online business (while tracking IP address in not enough), demands monitoring money transfers which requires the cooperation of law enforcement authorities and financial organizations. ${ }^{34}$

29 J. Wei, Chinese Foreign Investment Laws and Policies: Evolution and Transformation, Westport, CN 1994.

${ }^{30}$ Tax Justice Network, http://www.financialsecrecyindex.com/faq/what-is-a-secrecy-jurisdiction (accessed: 11.11.2017).

31 J. Zarobell, How Freeports Operate...

32 R. Blumenthal, T. Mashberg, TED Prize Goes to Archaeologist Who Combats Looting with Satellite Technology, "The New York Times”, 8.11.2015, https://www.nytimes.com/2015/11/09/arts/ international/ted-grant-goes-to-archaeologist-who-combats-looting-with-satellite-technology. html (accessed: 11.11.2017).

33 As per Andrzej Stepnowski, Professor at the Faculty of Electronics and Telecommunication, University of Gdańsk (interview on November 15, 2017).

34 As per Tomasz Paszkowski, Cloud Solution Architect, Intel Corporation (interview on November 13, 2017) 


\section{Conclusion}

The development of the Asian art market and its fundamental relationship with the European (and American) markets may foster improvements in preventing illicit trade of cultural goods and help establish the scope of international regulations. In time, it may be confronted with more and more regulations and bodies. ${ }^{35}$ Looted art databases (including only patched information) and published auction catalogues, offer a partial ground for exploration. On the other hand, adding more layers to enforcement might not be as sufficient as improving the execution of existing laws by investing in more resources. ${ }^{36}$ The manifold issue of Asian art on the European market gives grounds for further exploration. A deep revision of regulations governing the market and the strive for uniformity is not the only aspect present in the literature, however the lack of common practices proves to be the main embers in the context of cross-boundary trade (especially in reference to the secrecy jurisdictions). In the case of relatively new markets, such as the Polish art market, the shortage of art experts in Asian art appraisal and valuation is an additional limit causing concerns in the provenance research related to that kind of goods. In fact, it drives owners to search for reliable opinion abroad and, therefore, expose their collections of dubious nature to export control, which, in the end, might cause the owner to conceal an unverified object. Despite specific guidance on taxation in relation to importing antiques, ${ }^{37}$ the very question of identification and classification of a given object poses difficulties without a verified source of information. It is, therefore, prerequisite to develop studies as well as establish a network of certified experts in this subject matter. ${ }^{38}$

35 E.g. EuNAT (European Network of Advisory teams), Eurojust (Judicial Cooperation Unit of the European Union), Europol (European Police Office) and CEPOL (European Police College), European Commission, https://ec.europa.eu/culture/policy/culture-policies/trafficking en (accessed: 11.11.2017).

36 Art and Finance Report 2016...

37 E.g. Pursuant to the Polish act on goods and services tax of 2004, antiques are defined as objects older than 100, resulting from a human activity and constituting part of a bygone era; more: the law of July 23, 2003, on the protection of objects of cultural importance and their care (i.e.: Journal of Laws 2017, item 2187) (ustawa z dnia 23 lipca 2003 r. o ochronie zabytków i opiece nad zabytkami) and the law of March 11, 2004, on tax on goods and services (i.e.: Journal of Laws 2017, item 1221) (ustawa z dnia 11 marca 2004 r. o podatku od towarów i usług).

38 As of today, the profession of an art expert is not regulated by law: M. Bryl, Rynek sætuki $w$ Polsce. Poradnik dla kolekcionerón i inwestorów, Warszawa 2016, p. 41. On the other hand, in France, the Syndicat National des Antiquaires (SNA) influences the security measures of a gallery exporting works for exhibition, therefore such networks as its Polish equivalent might also take part in establishing such networks. 


\title{
STRESZCZENIE
}

\section{AZJATYCKIE DOBRA KULTURY W EUROPIE. EKSPANSJA RYNKU SZTUKI I NIELEGALNY HANDEL DZIEDZICTWEM KULTURY - ZARYS ZAGADNIEŃ PRAWNYCH}

\begin{abstract}
Wzrost znaczenia azjatyckiego rynku sztuki, jego silny związek z europejskimi i amerykańskimi rynkami bezpośrednio wpływa na wzmocnienie sposobów zapobiegania nielegalnemu handlowi dobrami kultury i poszerzenie zakresu regulacji międzynarodowych. Kluczowa rolę w badaniu tak zdefiniowanego problemu odgrywa rozwój technologii oraz dostępność baz dzieł zagrabionych i katalogów aukcyjnych. Niewystarczająca zmiana przepisów regulujących rynek sztuki nie jest jedynym aspektem obecnie podejmowanym w literaturze przedmiotu. Brak jednolitych przepisów prawnych okazuje się podstawowym problemem w obrocie dziełami sztuki między Europą a Chinami, ze szczególnym uwzględnieniem specyfiki Hongkongu. Innym zagadnieniem ważnym szczególnie w przypadku rynków rozwijających się, takich jak polski rynek sztuki, jest problem identyfikacji i kategoryzacji azjatyckich dóbr kultury. Warunkiem koniecznym do rozwoju badań, poza dostosowaniem przepisów, jest stworzenie sieci certyfikowanych ekspertów w tej materii.
\end{abstract}

